\title{
PENDIDIKAN LITERASI MEDIA PADA GURU TK GUGUS KASUNANAN SEBAGAI UPAYA MENANGGULANGI DAMPAK NEGATIF TELEVISI
}

\author{
$\frac{\text { Agus Triyono }}{\text { Jurusan Ilmu Komunikasi - Fakultas Komunikasi dan Informatika }}$ \\ Universitas Muhammadiyah Surakarta \\ agustri@fki.ums.ac.id
}

\begin{abstract}
Television as part of the development of technology has been able to change the way human life ranging from how to speak, dress, etc. chivalry ethics. Reality is there the community is very far from what is called intelligent concept of media. Many parents who do not pay attention to media consumption by their children and how much impact negetif raised by TV. Efforts to revive awareness of members of the Society of Teachers Kindergarten Cluster Mangkunegaran about the negative influence of TV with the concept of media literacy is expected to be applied in everyday life, has been able to open the horizons of thought participants to the impact of TV. Critical attitude toward TV has begun to take shape that comes to the end they hope to have a real action from the government to fix the TV programs in Indonesia.
\end{abstract}

Kata kunci: media literasi, anak, sekolah

\section{PENDAHULUAN}

\section{Analisis Situasi}

Munculnya TV dalam kehidupan masyarakat dengan berbagai fasilitas yang disediakannya, telah mengubah gaya hidup manusia. TV seolah menjadi alat pemuas kebutuhan manusia. Bagaimana tidak? Televisi telah menyulap hampir seluruh isi dunia untuk habis ditonton dalam sekali duduk. Televisi benar-benar telah menjelma menjadi jendela dunia atau bahkan dunia itu sendiri. Perkembangan televisi yang sangat pesat jelas menggambarkan bahwa media ini begitu digandrungi masyarakat Indonesia. Pada waktu TVRI, stasiun televisi pertama di Indonesia, muncul di tahun 1962 jumlah pesawat televisi di Jakarta hanya berjumlah 10.000 buah. Tujuh tahun kemudian jumlahnya meningkat menjadi 65.000 buah. Pada akhir maret 1972 jumlah pesawat televisi di Indonesia ada 212.580 buah, sampai tahun 1984 berjumlah 7.132 .462 buah. Hanya dalam kurun waktu 12 tahun jumlah pesawat televisi di Indonesia meningkat sampai hampir 34 kali lipat (Ishadi, 1999). Untuk saluran siaran pun, hingga tahun 2005 terdapat 10 stasiun televisi swasta dan tidak kurang dari 30 stasiun televisi lokal (Siregar, 2007). Dan saat ini, seperti yang telah kita maklumi bersama, televisi telah berubah menjadi teman makan atau bahkan teman tidur.

Kedahsyatan televisi dalam mempengaruhi pemirsanya tidak perlu diragukan lagi. Dwyer, seorang pakar pertelevisian menyimpulkan setidaknya pemirsa televisi mampu mengingat $50 \%$ materi yang hanya ditayangkan satu kali kali oleh televisi. Bisa 
dibayangkan berapa banyak pemirsa mampu mengingat jika tayangan itu ditampilkan berulang-ulang. Lebih jauh lagi, pemirsa televisi masih mampu mengingat $85 \%$ tayangan televisi yang mereka saksikan setelah tiga jam kemudian dan bahkan masih tersisa $65 \%$ ingatan akan tayangan Dan yang paling luar biasa, televisi mampu menjadi saluran yang paling efektif dalam menyampaikan informasi kepada manusia dengan merebut $94 \%$ dari seluruh saluran penyampaian pesan-pesan dan informasi kepada manusia (Dwyer, 1988). Melihat fakta diatas, tidak berlebihan rasanya jika televisi benarbenar telah menjadi fenomena baru dalam masyarakat kita.

Dengan fakta dan pemahaman tersebut, maka televisi jelas memiliki pengaruh yang tidak sedikit dalam meyebarkan informasi kepada masyarakat luas. Berat rasanya untuk tidak mengatakan bahwa televisi telah menjadi "kitab suci" baru bagi masyarakat kita. Bahkan bukan hanya sebatas kitab suci, TV telah mampu menjadi Agama baru bagi masyarakat. Sungguh disayangkan memang. Hampir semua pembicaraan menggunakan televisi sebagai rujukan. Mulai dari obrolan santai di warung kopi, diskusi di kampus, sampai khotbahkhotbah di masjid. Namun sayangnya, kemampuan televisi untuk menjadi saluran informasi paling efektif tidak diimbangi dengan kualitas informasi yang ditayangkan. Hampir semua tayangan televisi adalah semu atau rekaan belaka. Lebih tepatnya, tayangan televisi adalah sebuah simulasi. Sebuah citra tanpa referensi-suatu simulakrum.

\section{Perumusan masalah}

Masalah utama pada pengabdian kali adalah rendahnya pemahaman masyarakat tentang literasi media. Sehingga sebagai seorang guru TK yang senantiasa berdekatan dengan anak, perlu mendapatkan pengetahuan yang cukup tentang bagaimana memanfaat- kan media dengan baik agar bermanfaat bagi perkembangan anak.

\section{Tinjauan Pustaka}

a. Hypereality

Berbicara tentang citra, Baudrillard membagi empat fase perkembangan citra atau image, yaitu. Pertama, citra adalah cerminan atau refleksi dari realitas. Kedua, citra membelokkan realitas. Ketiga, citra menutupi realitas dan yang keempat, citra sama sekali tidak berkaitan dengan realitas apapun : citra merupakan simulakrum murni (Baudrillard dalam Piliang, 2003: 134). Dan sekarang citra yang ditampilkan televisi telah mencapai fase simulakrum atau simulakra. Tayangan-tayangan televisi tidak lebih dari sebuah dongeng besar untuk meninabobokan pemirsa. Sebut saja sinetron religi yang tak jelas landasannya sampai sinetron dan film "hantuhantuan" yang menyesatkan. Atau tayangan yang berbau kekerasan dan seks sampai sinetron dan program acara remaja yang penuh dunia glamor. Dan yang paling berbahaya, tayangan pemberitaan di televisi ternyata telah menjadi hantu simulakra yang paling menakutkan. Bagaimana tidak, tayangan pemberitaan televisi tidak lagi mencerminkan keadaan yang sebenarnya namun sudah menjadi kenyataan itu sendiri. Inilah yang disebut Baudrillard sebagai hyperreality atau realitas semu.

Melihat ini semua, sudah selayaknya lah rasa khawatir yang besar perlu dialamatkan kepada bangsa ini. Simulakra-simulakra yang ditampilkan televisi jelas menghadirkan dampak yang tidak sedikit kepada masyarakat Indonesia yang telah menjadikan televisi sebagai salah satu anggota keluarga. Perlu perhatian serius terhadap masalah ini. Dampak yang masih terlihat samar 
kadang membuat bangsa ini lupa. Bahwa hyperreality yang direkayasa televisi ini sungguh berbahaya.

Sekilas dampak simulasi media untuk membentuk hyperreality ini memang tidak tampak namun realitas semu ini akan sangat berbahaya. Tengok saja berapa banyak remaja yang telah terjangkit virus glamor yang ditampilkan sinetron remaja masa kini. Para remaja yang notabene berada dalam situasi psikologis yang kritis dalam dirinya terkait pencarian jati diri mendapatkan tayangan kehidupan remaja dari sinetron. Hyperreality menyebabkan remaja terperangkap dalam sesuatu yang tidak nyata (semu) dan menganggap kondisi demikianlah yang sebenarnya ada dalam dunia remaja. (Eka Nada Shofa Alkhajar dalam Kompas, 28 Desember 2007).

Atau dampak dari fenomena tayangan kekerasan "Smackdown" yang meminta korban jiwa beberapa waktu yang lalu. Anak-anak yang telah kena sihir simulakra "Smackdown" dengan serta merta mengidentifikasi diri sesuai dengan karakter yang ada dalam tayangan kekerasan itu dan bertarung layaknya tokoh idolanya tersebut. Tidak heran jika kemudian jatuh korban cedera yang cukup serius dan bahkan korban jiwa.

Beberapa contoh tayangan televisi diatas jelas sesat menyesatkan. Jika tak segera diantisipasi, sepertinya akan banyak korban lain akibat tayangan horor, sinetron religi yang kebablasan atau tayangan yang mengumbar seks secara berlebihan. Gagasan kreatif yang bisa dilakukan untuk setidaknya mengurangi dampak simulasi media atau bahkan pada tingkat yang lebih jauh, melindungi masyarakat dari "kejahatan" media adalah membentuk masyarakat yang cerdas media atau masyarakat yang cerdas menggunakan media.

\section{b. Literasi Media}

Media Literacy atau Literasi Media adalah konsep yang digagas sebagai sebuah "benteng" dalam menghadapi serangan acara media (TV khususnya) yang berkualitas rendahuntuk tidak mengatakan tidak berkualitas. Literasi media menawarkan sebuah konsep mencerdaskan siapapun yang berhadapan dengan media. Literasi media dalam hal ini menjadi hal yang mendesak sekaligus penting untuk diterapkan pada masyarakat mengingat posisi masyarakat yang berhadapan langsung dengan media. Relasi masyarakat dengan media bukanlah relasi yang bersifat mekanis dan linear tapi bersifat multidimensi dan menyentuh aspek sosiologis. Dalam hal ini masyarakat dipandang sebagai pihak yang aktif dalam hubungannya dengan media. Sehingga masyarakat setidaknya menyadari gerak langkah media ketika menebarkan pengaruhnya. Namun sayangnya, tidak banyak masyarakat yang menyadari hal ini. Lebih banyak masyarakat yang tenggelam dalam hiruk pikuk tayangan-tayangan media yang berkualitas rendah. Untuk itu, literasi media dipandang sebagai sebuah solusi alternatif yang paling rasional untuk memberikan edukasi kepada masyarakat tentang pengaruh tayangan media.

Sebuah gagasan lain dalam menghadapi tayangan media pernah hadir ditengah-tengah masyarakat lewat konsep media watch. Namun sayangnya, media watch hanya sampai pada tataran elit. Hanya kalangan aktivis media dan akademisi yang bisa ikut menikmati manfaat dari media watch. Masyarakat cenderung pasif. Lain halnya dengan literasi media, masyarakat luas bahkan menjadi ujung tombak dalam menyukseskan gerakan literasi media. Literasi media mengedukasi masyarakat agar 
mampu mengakses, memilih tayangan yang berkualitas sampai menafsirkan pesan media. Dengan tidak mengesampingkan media watch, literasi media memang diharapkan mampu "mencerdaskan" masyarakat dalam memahami media. Bahkan sampai tingkat lanjut. Media watch tetap harus dikembangkan untuk terus memonitor media dan mengadvokasi warga masyarakat ketika haknya dilanggar media.

Medesaknya gerakan literasi media ini selain untuk melindungi masyarakat dari serangan media adalah juga untuk memberi stimulan bagi masyarakat dalam memperoleh informasi dari media. Kondisi saat ini menunjukkan bahwa masyarakat tetap saja tidak memperoleh informasi yang multiperspektif ditengahtengah tayangan media yang beragam. Hal ini jelas dipicu sebagai homogenitas program dan kesamaan perspektif dalam menampilkan informasi.

Diantara kelompok masyarakat yang harus dan paling dilindungi dari "serangan" media adalah anak-anak. Hal ini karena anak adalah masa depan. Apa jadinya jika sejak anak-anak pun generasi penerus ini telah diracuni media. Perlindungan dari tayangan media yang berkualitas rendah ini patut mendapat sorotan serius mengingat anak adalah kelompok masyarakat yang paling rentan terhadap "serbuan" media. Tidak heran karena anak-anak adalah kelompok masyarakat yang paling sulit untuk memebedakan antara dunia nyata dengan dunia semu yang dihadirkan media.

Pokok permasalahan yang paling besar, sebenarnya adalah ketidakmampuan anak membedakan dunia yang ia lihat di TV dengan apa yang sebenarnya (Leman, 2000). Bagi orang dewasa, kehadiran Rambo, Kuntilanak, Superman serta tokoh-tokoh televisi lainnya adalah tidak lebih dari sebuah gambaran fiktif belaka. Namun tidak bagi anak-anak, tokoh-tokoh jagoan bagi mereka adalah nyata. Tidak heran jika banyak anak yang ingin terbang seperti Superman atau kuat seperti tokoh jagoan mereka lainnya. Selain itu, anak-anak adalah kelompok masyarakat yang paling mudah meniru. Apalagi jika model tiruan itu disampaikan dalam bentuk audio visual.

Selain itu masa anak-anak adalah masa laten. Semua yang dilihat oleh anak akan sangat mudah teringat olehnya. Walaupun anak belum memperlihatkan responnya segera setelah ia menonton, bukan tidak mungkin semua yang dilihatnya akan ia praktikkan kelak dikemudian hari (Elia, 1996).

Sebut saja Kidia, sebuah yayasan yang concern pada permasalahan anak dan media, memaparkan beberapa fakta yang menunjukkan dampak buruk dari penayangan televisi terhadap anak. Data tahun 2006 menunjukkan bahwa jumlah jam menonton TV pada anak-anak usia sekolah dasar berkisar antara 30-35 jam seminggu, ditambah dengan sekitar 10 jam untuk bermain video game. Angka ini jauh lebih besar dibanding jam belajar disekolah yang tidak sampai 1000 jam per tahun. Saat ini jumlah acara TV untuk anak usia prasekolah dan sekolah dasar perminggu sekitar 80 judul ditayangkan dalam 300 kali penayangan selama 170 jam. Padahal dalam seminggu ada 24 jam x $7=168$ jam! Dari sekian banyak program yang dilihat, banyak program yang tidak layak dikonsumsi oleh anak.

Melihat begitu besarnya pengaruh siaran televisi terhadap anak dan mengingat bahwa anak adalah harapan di masa depan maka tidak heran jika proteksi terhadap anak dari "serangan" media ini harus mendapat perhatian lebih serius. 
Konsep literasi media-yang disinggung sebelumnya-adalah salah satu langkah cerdas dalam menahan serangan media terhadap anak. Gerakannya yang lebih dekat dengan masyarakat luas menyebabkan literasi media menjadi gagasan yang mudah untuk diterapkan. Dalam kasusnya untuk memproteksi anak, literasi media memang patut untuk dipertimbangkan lebih lanjut. Mengingat proses pengaplikasiannya bisa diterapkan di lingkungan sekolah dan keluarga. Dua habitat yang paling dekat dengan anak.

\section{c. Sekolah dan Agen Sosialisasi}

Menerapkan paradigma pendidikan kritis dalam mengembangkan pendidikan literasi media berbasis sekolah dan komunikasi efektif dalam keluarga mempunyai latar belakang yang sangat relevan. Paradigma pendidikan kritis yang mengunggulkan konsep partnership dalam pembelajaran tentu sangat sesuai diterapkan dalam sekolah maupun kelurga karena konsep partnership yang menawarkan model pembelajaran yang dialogis sekaligus partisipatoris. Selain itu, paradigma pendidikan kritis yang mengajak untuk sadar akan kondisi realitas sosial dan realitas diri juga akan sangat membantu pengembangan pendidikan literasi media yang mengajak masyarakat untuk kritis dalam memahami media.

Paradigma pendidikan kritis yang membebaskan juga menyebabkan siswa akan sangat leluasa dalam menggunakan kemampuan literasi medianya. Hal ini pada gilirannya akan menghasilkan pendidikan literasi media yang efektif. Tanpa ada belenggu, siswa akan dengan bebas dalam mempelajari literasi media. Bisa dibayangkan, siswa yang telah memahami realitas media dan realitas sesungguhnya melalui gerakan kesadaran yang ditawarkan paradigma pendidikan kritis akan semakin luar biasa dengan gerakan membebaskan dalam memberikan solusi positif atas realitas sosial yang ada.

Mengambil pendekatan sekolah dan keluarga jelas memiliki alasan yang kuat. Seperti yang telah diungkapkan diatas, lingkungan terdekat anak adalah sekolah dan keluarga. Dalam keluarga, anak menemukan pendidikan pertamanya. Semua yang diajarkan keluarga pasti akan meninggalkan sebuah ingatan mendalam bagi anak. Fenomena sekarang, banyak orang tua yang "menyerahkan" anaknya untuk "dididik" televisi tentu suatu hal yang memprihatinkan. Maka sungguh wajar jika ada istilah "anak disusui televisi". Atau televisi telah menjadi "baby sitter" baru bagi anak. Padahal-seperti yang telah diuraikan diatas-dampak televisi dangat buruk. Menonton televisi terlalu dini bisa menyebabkan proses wiring, proses penyambungan antarasel syaraf dalam otak menjadi terganggu (Soendjojo dalam Wirodono, 2004: 142). Melihat efek buruk yang dihadirkan televisibahkan dalam ruang paling privat (ruang keluarga) sekalipun-itulah pendidikan berbasis keluarga penting untuk dilakukan. Salah satu syarat yang harus dipenuhi untuk mendukung terbentuknya pendidikan keluarga yang baik salah satunya adalah komunikasi yang efektif dalam keluarga. Dalam hal ini adalah komunikasi antara anak dengan orang tua, yang notabenenya adalah pendidik pertama bagi anak. Jika komunikasi efektif ini telah terjalin tentu semuanya akan berjalan dengan baik.

Pada tingkat selanjutnya, pendidikan yang harus ditempuh anak setelah pendidikan keluarga adalah pendidikan 
sekolah. Saat ini, masa awal pendidikan anak sungguh sangat dini. Kurang dari usia enam tahun, anak sudah masuk pendidikan formal. Apalagi jika melihat pada format pre school, yang mulai mendidik anak yang baru berusia tiga tahun. Melihat hal demikian, maka tidak heran jika salah satu pendidikan literasi media yang patut dikembangkan adalah pendidikan literasi media yang berbasis sekolah. Waktu yang sangat luang yang dimiliki sekolah untuk mendidik anak menjadi alasan selanjutnya. Dengan waktu 4-7 jam sehari, sekolah tentu memiliki waktu yang lebih dari cukup untuk menerapkan pendidikan literasi media pada anak. Selain itu, fasilitas yang dimiliki sekolah berupa tenaga pendidik, ruang kelas dan sarana serta prasarana lainnya semakin menguatkan wacana bahwa sekolah adalah tempat yang tepat untuk mendidik literasi media pada anak. Terlepas dari kritik dan kelemahan terhadap yang ada dalam sistem pendidikan Indonesia, sekolah tetap menjadi sentral dalam sistem pendidikan., dan karenanya mempunyai feasibilitas dan aksesibilitas yang sangat tinggi dibandingkan dengan institusi yang lain (Rianto, 2004)

Pada akhirnya bila pendidikan awalnya sudah baik maka bukan tidak mungkin anak akan kebal terhadap pengaruh media. Semua hal memang harus terus dilakukan untuk "melindungi" anak dari pengaruh efek jelek media. Bukan hanya karena anak adalah generasi penerus, lebih dari itu, anak adalah sebuah amanah Tuhan dan tanggungjawab untuk memberikan semua yang terbaik untuknya.

\section{Tujuan dan Manfaat}

Tujuan dan manfaat pengabdian kali ini adalah untuk: a. Memberikan wawasan seberapa efektif literasi media dalam menangkal simulasi dan hypereality yang dihadirkan media televisi.

b. Menjelaskan bahwa bagaimana sebenarnya peran institusi pendidikan dalam mendukung pengembangan pendidikan literasi media.

\section{METODE PELAKSANAAN}

Metode kegiatan dalam Pendidikan Literasi media ini adalah dengan ceramah, tanya jawab dan pemberian modul. Bahanbahan untuk kegiatan ini adalah modul mengenai pentingnya media literasi (khususunya ketika diterapkan di wilayah akademik dan keluarga). Bertindak selaku pemberi materi dalam pengabdian ini adalah dosen dari Fakultas Komunikasi dan Informatika UMS dengan sistem interaktif dan dilengkapi dengan fasilitas audio visual sebagai sarana penunjang. Adapun materi yang akan disampaikan antara lain :

1. Agus Triyono, S.Sos dengan tema: Pendidikan Media, Membangun Sikap Kritis Anak dalam Menggunakan Media

2. Nur Latifa, S.Sos dengan tema : Tidak Semua Kartun Cocok Untuk Anak

\section{HASIL DAN PEMBAHASAN}

Semua orang pada dasarnya melek media. Tidak ada yang benar-benar tidak melek media atau tidak ada yang begitu mengenal media. Jadi, pengelompokan literasi media tidak bisa dalam sebuah pengkotakan mengerti atau tidak. Tingkatan literasi media seseorang lebih mirip tingkatan dalam termometer. Ada tingkatan level dalam literasi media. Semakin tinggi tingkat literasi media seseorang maka semakin kuat dalam memahami makna pesan yang disampaikan media.

Seseorang yang tingkat literasi medianya rendah akan sulit untuk menilai 
ketidakakuratan media, keberpihakan media, memahami kontroversi media atau meapresiasi ironi yang ditampilkan media. Bahkan kemungkinan besar, seseorang yang literasi medianya rendah akan menerima begitu saja pesan-pesan dan pengaruh media tanpa mau mengkritisinya. Bahkan menurut Aufderheide (Berg dalam Rahayu: 2004) literasi media diorientasikan untuk meningkatkan kemampuan individu dalam mengakses, menganalisis, mengevaluasi dan menyusun informasi dalam format media. Pemahaman atas literasi media diatas menolak pemahaman sempit atas literasi media berupa kemampuan memahami (membaca) dan memproduksi informasi media. Lebih jauh, literasi media mencakup aktivitas mengakses, menganalisis, mengevaluasi dan mengkritisi informasi yang disampaikan media.

Untuk mewujudkan literasi media tadi tentu dibutuhkan pemahaman lebih atas konsep-konsep utama media. Rahayu merumuskan setidaknya ada empat konsep utama media. Diantaranya, Pertama, media merupakan hasil konstruksi. Semua informasi yang disampaikan media telah melalui proses pengkonstruksian. Telah melalui proses pembentukan yang melibatkan banyak aspek. Ideologi media, kepentingan bisnis, dan situasi sosial politik adalah beberapa hal yang mempengaruhi media dalam memproduksi informasi. Perlu pemahaman yang lebih tentang real world dan media world. Aufderheide mengatakan "media are constructed and construct reality" (Christ dalam Rahayu: 2004). Kedua, representasi media mengontruksi realitas. Hal ini menyebabkan apa yang disebut dengan hadirnya hyperreality atau hiperrealitas dalam dunia nyata. Perlu diketahui, ketika seseorang tidak mempunyai referensi lain atas suatu peristiwa selain media, ia akan amenganggap semua yang ditampilkan media adalah hal yang sebenarnya. Ketiga, pesan media berisi nilai dan ideologi. Seperti yang telah dijelaskan diatas. Dalam mengkonstruksi realitas tadi media dipengaruhi oleh nilai dan ideologi. Ini yang harus dipahami, termasuk memahami ideologi dan nilai apa yang dibawa suatu media. Keempat, pesan media berimplikasi sosial dan politik. Karena dipercayai sebagai institusi yang merefleksikan realitas maka sering kali media dianggap netral. Namun media sesungguhnya mengkonstruksi realitas-yang kemudian dipahami masyarakat—sehingga memiliki konsekuensi sosial dan politik.

Konsep literasi media atau media literacy berbeda dengan media education. Namun kedua hal ini akan selalu berhubungan. Media education lebih berorientasi pada meningkatkan pengetahuan khalayak tentang media dilihat dari sisi teks, makna dan relasinya dengan masyarakat. Namun media literacy lebih spesifik karena berfokus pada penyikapan terhadap media. Media education berperan besar terhadap literasi media karena memperkaya pengetahuan masyarakat hingga pada gilirannya akan menambah refernsi masyarakat untuk tanggap dalam menyikapi media.

\section{Model Pengembangan Literasi Media}

Dalam dunia ilmu pengetahuan, model merupakan repesentasi atas realitas (Grunig dan Grunig dalam Rianto: 2004) atau lebih tepatnya representsi atas realitas yang disederhanakan. Pikiran manusia tdak akan sanggup meng-capture realitas. Namun sanggup memilah-milah realitas, dan memilih bagian atas dari suatu realitas untuk selanjutnya menyusunnya menjadi sebuah gagasan. Kita tidak akan mampu memahami realitas jika tidak memiliki model yang bekerja untuk menggambarkan realitas yang dimaksud (Grunig dan Grunig dalam Rianto: 2004).

Dalam konteks pendidikan literasi media, beberapa negara telah mengem- 
bangkan berbagai model pendidikan literasi media. Salah satunya adalah eCLIPse Project (Cilia dalam Rianto: 2004) Dalam mengembangkan model pendidikan litersi media, eCLIPse Project menyandarkan pada empat hal pokok. Pertama, contructivism and learning. Individu secara aktif membangun pengetahuan melalui kerja guna memecahkan masalah. Kedua, project-based learning. Belajar melalui proses penemuan dan biasanya memakan waktu jangka panjang. Ketiga, collaborative learning. Pembelajaran melalui interaksi antar-kelompok, antar-para pembelajar. Keempat, learning and critical thinking. Kompetensi untuk berpikir kritis. Termasuk didalamnya ada tiga kategori, yakni: Pertama, kemampuan melakukan analisis terhadap informasi. Kedua, kemampuan melakukan justifikasi atau penilaian terhadap reliabilitas informasi. Ketiga, kemampuan melakukan evaluasi.

\section{Pengembangan Pendidikan Literasi Media Berbasis Sekolah}

Memilih sekolah sebagai wahana pengembangan pendidikan literasi media memang membutuhkan alasan yang kuat. Sekolah sebagai salah satu ruang pendidikan bagi anak setelah keluarga jelas merupakan sebab kenapa pendidikan literasi media ini perlu diterapkan di ruang pendidikan formal ini. Sebelum memutuskan model apa yang kiranya sesuai untuk diterapkan di sekolah tentu kita harus melihat terlebih dahulu kondisi elemen-elemen yang ada di sekolah. Seperti tenaga pendidik, kurikulum atau siswa sendiri. Secara umum kondisi sesungguhnya pendidikan di Indonesia adalah sebagai berikut: Pertama, kurikulum pendidikan di Indonesia sudah sangat padat. Kurikulum pendidikan begitu membebani siswa sehingga sulit untuk memasukkan literasi media ke dalam kurikulum pendidikan sekolah. Kedua, kondisi sekolah yang diisi yang oleh latar belakang siswa yang beragam. Mulai dari latar belakang ekonomi, sosial dan budaya. Ketiga, pemahaman guru akan literasi media masih tergolong rendah. Diantara guru ada yang memandang literasi media sebagai media for education dalam pengertian bahwa media dalam hal ini, video, OHP dan sejenisnya sebagai alat pembelajaran (Rianto: 2004).

Melihat permasalahan diatas, paradigma pemikiran kritis layak untuk dipertimbangkan sebagai salah satu solusi alternatif. Penerapannya yang tidak memerlukan alokasi waktu khusus tentu sesuai dengan kurikulum Indonesia yang sangat padat. Pendidikan kritis yang lebih mengedepankan penyadaran dan pembebasan dalam melihat realist sosial jelas tidak akan mengalami hambatan yang berarti dengan beragamnya kondisi sosial, ekonomi, dan budaya siswa. Paradigma pendidikan kritis yang mengagungkan konsep partnership dalam proses pembelajaran tentu sangat membantu guru untuk menerapkan literasi media, walaupun guru tidak terlalu memahami literasi media secara mendalam. Namun gagasan untuk mengadakan training literasi media bagi para pendidik sangat menarik untuk dipertimbangkan.

Lebih lanjut, nilai-nilai yang ada dalam paradigma pendidikan kritis, seperti: partnership, menyadarkan, membebaskan atau mencerahkan akan sangat sesuai bagi pengembangan pendidikan literasi media di sekolah. Beberapa konsep setidaknya bisa ditawarakan dalam menerapkan paradigma pendidikan kritis berbasis sekolah dalam mengembangkan pendidikan literasi media bagi anak, diantaranya adalah: Pertama, paradigma pendidikan kritis yang mengagungkan partnership dalam pembelajaran akan sangat berguna dalam mengembangkan pendidikan literasi media bagi anak. Dengan posisi guru dan siswa sebagai partner maka akan dengan mudah bagi guru dalam menyampaikan materi tentang literasi media. 
Suasana dialogis akan sangat terasa karena siswa tidak akan sungkan untuk bertanya atau bahkan mendebat guru mengingat posisi siswa dan guru adalah partner. Gaya partnership yang ditawarkan juga akan memudahkan guru untuk mencari pola pengajaran yang baik untuk anak. Dengan permainan misalnya, permainan akan terasa hidup karena guru adalah “teman”. Sehingga partisipasi siswa akan lebih banyak karena siswa tidak menganggap guru lebih pintar dari dirinya. Siswa dan guru adalah subyek dalam pembelajaran.

Paradigma pendidikan kritis yang menawarkan konsep penyadaran juga sangat bermanfaat dalam pengembangan pendidikan literasi media di sekolah. Siswa dididik untuk peka terhadap kondisi realitas sosial dan realitas diri. Dalam hal ini, siswa dididik untuk mampu memahami bahkan menganalisa tayangan televisi yang dipenuhi oleh nilai-nilai yang tidak mendidik. Siswa diajak untuk mengerti bahwa kenyataan yang ada di televisi bukanlah kenyataan yang sebenarnya. Semua kenyataan itu hanyalah konstruksi media dan semua yang hadir hanyalah hyperreality, realitas semu. Tawaran dari paradigma pendidikan kritis untuk berani "sadar" tadi tentu sangat penting. Siswa harus diajak untuk meninggalkan kesadaran magis dan kesadaran naifnya menuju kesadaran kritis atau bahkan kesadaran transformatif. Sadar bahwa realitas media bukan lah realitas sebenarnya harus segera ditanamkan pendidikan literasi media berbasis sekolah, dan sepertinya paradigma pendidikan kritis yang "menyadarkan" tentu sangat tepat untuk diterapkan.

Paradigma pendidikan kritis yang mengajak untuk meningkatkan kesadaran hingga ke tingkat kesadaran kritis atau bahkan kesadaran transformatif jelas akan merangsang siswa untuk berpikir kritis akan realitas media yang hanya semu belaka tersebut. Untuk selanjutnya akan memberi- kan solusi positif atas dampak dari hyperreality yang ditampilkan media. Paradigma pendidikan kritis yang membebaskan juga akan memberikan ruang kepada siswa untuk "liar" dalam memberikan ide-ide segar demi naiknya literasi media siswa. Paradigma pendidikan kritis yang menuntut adanya perubahan sosial akan sangat bersesuaian dengan agenda pendidikan literasi media yang ingin mengubah masyarakat-dalam hal ini adalah anak - menuju arah yang lebih baik dan lebih cerdas dalam memahami media.

Sekolah sebagai wahana sosialisasi yang utama bagi seorang siswa memang perlu menciptakan sebuah lingkungan dan kondisi yang mampu mendukung perkembangan psikologis seorang anak. Pardigma pendidikan kritis seperti tersebut diatas, tentunya tidak akan bermakna manakala guru tidak mempunyai satu pemahaman yang utuh akan pentinganya literasi media. Dari keseluruhan peserta pengabdian yang ada di lingkungan TK Gugus Kasunanan-Kartasura, kami menangkap bahwa ada sebuah antusiasme yang cukup tinggi yang dimiliki oleh para guru tersebut untuk menyelamatkan anak mereka beserta anak didiknya dari terpaan media.

Dengan ditampilkannya beberapa film yang berbahaya bagi anak (meskipun itu kartun), video game yang berbahaya kemudian dilanjutkan dengan beberapa program sinetron yang tidak tepat untuk diekpose melalui TV, para guru -yang sekaligus orang tua- menjadi lebih sadar tentang perlunya sebuah pengawasan program TV. Tidak hanya berhenti pada adanya pengawasan program TV, para guru tersebut juga bahkan menyampaikan tentang perlunya peran dari pemerintah untuk mengelola program siaran yang ada di negara ini. Dari mereka kemudian muncul sebuah ide besar perlu dibentuknya lembaga yang melakukan pengawasan terhadap tayangan yang ada di media massa (khususnya TV) 


\section{SIMPULAN}

Berdasarkan paparan diatas, maka dapat diambil kesimpulan bahwa :

1. Literasi media akan sangat efektif dalam menangkal efek buruk realitas media jika sebelumnya telah memahami konsepkonsep utama dalam media

2. Paradigma pendidikan kritis sangat mendukung pengembangan pendidikan literasi media yang mengharuskan untuk kritis terhadap tayangan media. Hal ini karena dalam paradigma pendidikan kritis, dituntut untuk mampu sadar dalam memahami realitas diri dan realitas sosial. Jika telah mampu "sadar" lewat pamahaman akan paradigma pendidikan kritis maka akan mudah mengembangkan pendidikan literasi media.

3. Pengembangan pendidikan literasi media berbasis sekolah melalui paradigma pendidikan kritis sangat efektif.
Mengingat sekolah adalah wahana yang paling dekat dengan anak. Sekaligus menjadi ruang pertama dan utama bagi anak dalam berinteraksi dengan realitas sosialnya.

\section{PERSANTUNAN}

Penulis mengucapkan terima kasih atas bantuan dan partisipasi dari Perkumpulan Guru TK Gugus Kasunanan Sukoharjo yang telah berkenan untuk menjadi mitra pelaksanaan pengabdian Media Literasi. Semoga saja kerjasama kita dapat berlanjut pada kesempatan mendatang. Kami juga ucapkan terimakasih kepada semua anggota pengabdian yang telah membantu proses pengabdian sehingga kegiatan dapat berjalan dengan optimal. Terima kasih juga kami sampaikan kepada LPPM dan Fakultas yang telah membantu kesuksesan acara ini.

\section{DAFTAR PUSTAKA}

Ishadi S.K. 1999. Dunia Penyiaran: Prospek dan Tantangannya. Jakarta: Gramedia.

Siregar, Amir Effendi. 2007. "Ekonomi Politik Media, Audiens dan Ketimpangan Informasi". Infomedia. Yellow Pages. Serikat Penerbit Surat Kabar.

Yasraf Amir Piliang. 2003. Hipersemiotika: Tafsir Cultural Studies Atas Matinya Makna. Yogyakarta: Jalasutra.

Wirodono, Sunardian. 2006. Matikan TV-Mu!, Yogyakarta: Resist Book.

Rianto, Puji. 2007. Mengembangkan Pendidikan Literasi Media Berbasis Sekolah, Jurnal Penelitian Ilmu Pengetahuan dan Teknologi Komunikasi. Yogyakarta: Balai Pengkajian dan 